\title{
Changes in seabed morphology, mud temperature and free gas venting at the Håkon Mosby mud volcano, offshore northern Norway, over the time period 2003-2006
}

\author{
Jean-Paul Foucher ${ }^{1,{ }^{*}}$, Stéphanie Dupré ${ }^{2}$, Carla Scalabrin ${ }^{1}$, Tomas Feseker $^{3}$, François Harmegnies ${ }^{1}$ \\ and Hervé Nouzé ${ }^{1}$
}

\author{
${ }^{1}$ Ifremer, Centre de Brest, BP 70 Plouzané 29280, France \\ ${ }^{2}$ LOCEAN, Université Pierre et Marie Curie Paris, France \\ 3 IFM-GEOMAR, Leibniz Institute of Marine Sciences at Kiel University, Kiel, Germany \\ *: Corresponding author : Jean-Paul Foucher, email address : joucher@ifremer.fr
}

\begin{abstract}
:
The Håkon Mosby mud volcano is a 1.5-km-diameter geological structure located on the Southwest Barents Sea slope at a water depth of 1,270 m. High-definition seabed mapping of the mud volcano has been carried out in 2003 and 2006. A comparative analysis of the bathymetry and backscatter maps produced from the two surveys shows subtle morphological changes over the entire crater of the mud volcano, interpreted to be the consequence of mud eruption events. Mud temperature measurements point to a persistently warm mud at shallow depth in the crater. This is explained by upward fluid advection, rather than conductive cooling of mud flows. The small-scale spatial variability in the temperature distribution may be related to mud outflows or changes in the fluid flow regime. Furthermore, the locations of free gas venting observed in 2006 were found to differ from those of 2003. Our observations of overall similar topographic profiles across the mud volcano in 2003 and 2006 suggest that eruption events would have been modest. Nevertheless, the data bring evidence of significant change in activity even over short time intervals of only 3 years. This may be a characteristic shared by other submarine mud volcanoes, notably those considered to be in a quiescent stage.
\end{abstract}




\section{Introduction}

Mud volcanoes are geological structures of mud eruption and fluid emission at the earth's surface (Milkov 2000). They occur worldwide in areas of rapid sedimentation or compressive tectonics, where deep over-pressurized muds and fluids reach the earth's surface through high permeability conduits such as faults and fractures. Episodic activity alternating with periods of quiescence is observed at most mud volcanoes over a lifetime of up to several hundred thousand years (Kopf 2002). Historical data available for several onshore mud volcanoes suggest a cyclic eruptive activity with catastrophic eruptions occurring at intervals of only a few years to several tens of years (Aliyev et al. 2002; Deville and Guerlais 2009). This activity would be mainly controlled by the local pressure regime within the sediment pile (Deville and Guerlais 2009), although seismic events could contribute to the trigger process (Delisle et al. 2002; Mazzini et al. 2007). Based on investigations of onshore mud volcanoes of the Crimean-Caucasus region, Herbin et al. (2008) distinguish various types of mud volcano activity, from an explosive type with a very high column of burning gas and a great volume of gas ejected, as exemplified by the catastrophic eruptions of the Dzau-Tepe mud volcano in the Kerch peninsula or the Lokbatan mud volcano in Azerbaijan, to a continuous or intermittent slow flow of mud and gas at gryphons, as observed at the surface of the Boulganack mud volcano in Ukraine. Other goals include a better assessment of amounts of methane and carbon dioxide greenhouse gases that may be released by mud volcanoes to the atmosphere (Dimitrov 2002; Etiope and Milkov 2004) or yet investigations of the biodiversity and biogeochemical processes at cold seeps (Foucher et al. 2009; Vanreusel et al. 2009). Whereas historical data provide useful information to decipher the temporal variability of the activity of onshore mud volcanoes over a time-scale of years or tens of years, this information is generally missing for deep offshore mud volcanoes. The Isis mud volcano on the Egyptian continental slope in the eastern Mediterranean Sea is one of a few submarine mud volcanoes where repeated measurements of mud temperature and pore water chemistry in the surface sediment over a 9 month interval have demonstrated a highly dynamic fluid flow regime (Feseker et al. 2009). Another submarine mud volcano along the European margins where repeated observations have been carried out is the Håkon Mosby Mud Volcano (HMMV) offshore northern Norway (Fig. 1a). In this paper, we analyse and interpret field data collected at the surface of the HMMV in 2006 during the Vicking cruise aboard the R/V Pourquoi pas?. We compare the new observations with those made in 2003 during the ARK-XIX/3b expedition aboard the R/V Polarstern. We bring evidence of and discuss changes in the morphology and fluid activity of the mud volcano over the time period 2003 to 2006.

\subsection{Geological setting}

The Håkon Mosby mud volcano is a geological structure of about $1.5 \mathrm{~km}$ diameter located on the Southwest Barents Sea slope in a water depth of $1270 \mathrm{~m}$ (Fig. 1). The mud volcano comprises three main morphological units (Fig. 2): (1) a flat central and southern part interpreted as an area of recent mud flows; this flat area was called crater by Milkov et al. (2004), a term that we will use in this paper, (2) a surrounding area characterized by an hummocky seafloor; this area is interpreted to be composed of deformed old mud flows, (3) a pronounced moat at the periphery of the mud volcano. These units are easily recognized on a recent high-resolution bathymetry map of the mud volcano produced from a deep-tow Victor ROV survey carried out in July 2003 aboard the R/V Polarstern during expedition ARK-XIX/3b (Edy et al. 2004), as shown in Fig. 1b. An earlier survey using a 30-kHz deeptow side-scan sonar also revealed mud flows extending down-slope to the southeast of the mud volcano (Vogt et al. 1999). The source level of the erupted mud and expelled fluids may lie within overpressurized oozes found below glacial deposits at depths of $2-3 \mathrm{~km}$ below the 
seabed (Hjelstuen et al. 1999). More recently, Perez-Garcia et al. (2009) described the evolution of the HMMV over the last 330,000 years and, based on acoustic and seismic data, inferred the presence of a pseudo-mud chamber and a funnel-shaped geometry of the shallow part of the conduit. Field observations made during successive oceanographic expeditions have emphasized the concentric zones of litho-types, as well as of geochemical and biological processes at the surface of the mud volcano (Milkov et al. 1999, 2004; de Beer et al. 2006; Jerosch et al. 2007), and demonstrated an exceptionally high activity of fluid and gas ejections through the seabed (Sauter et al. 2006; Feseker et al. 2008). Geothermal modelling indicates aqueous flow rates of up to 4-10 $\mathrm{m} \mathrm{y}^{-1}$ at the centre of the mud volcano, rapidly decreasing to less than $1 \mathrm{~m} \mathrm{y}^{-1}$ in its outer part (Feseker et al. 2008). Free methane discharge could amount to several hundred tons per year (Sauter et al. 2006).

a

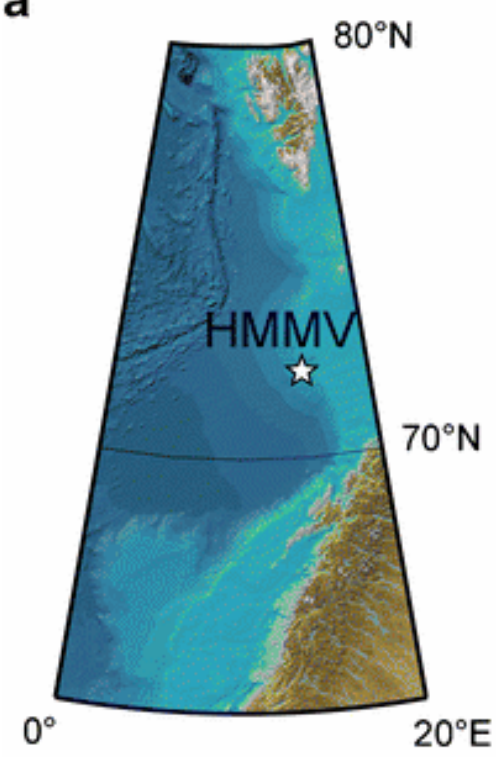

Bathymetry / topography ( $\mathrm{m})$

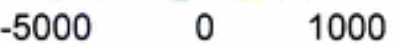

b

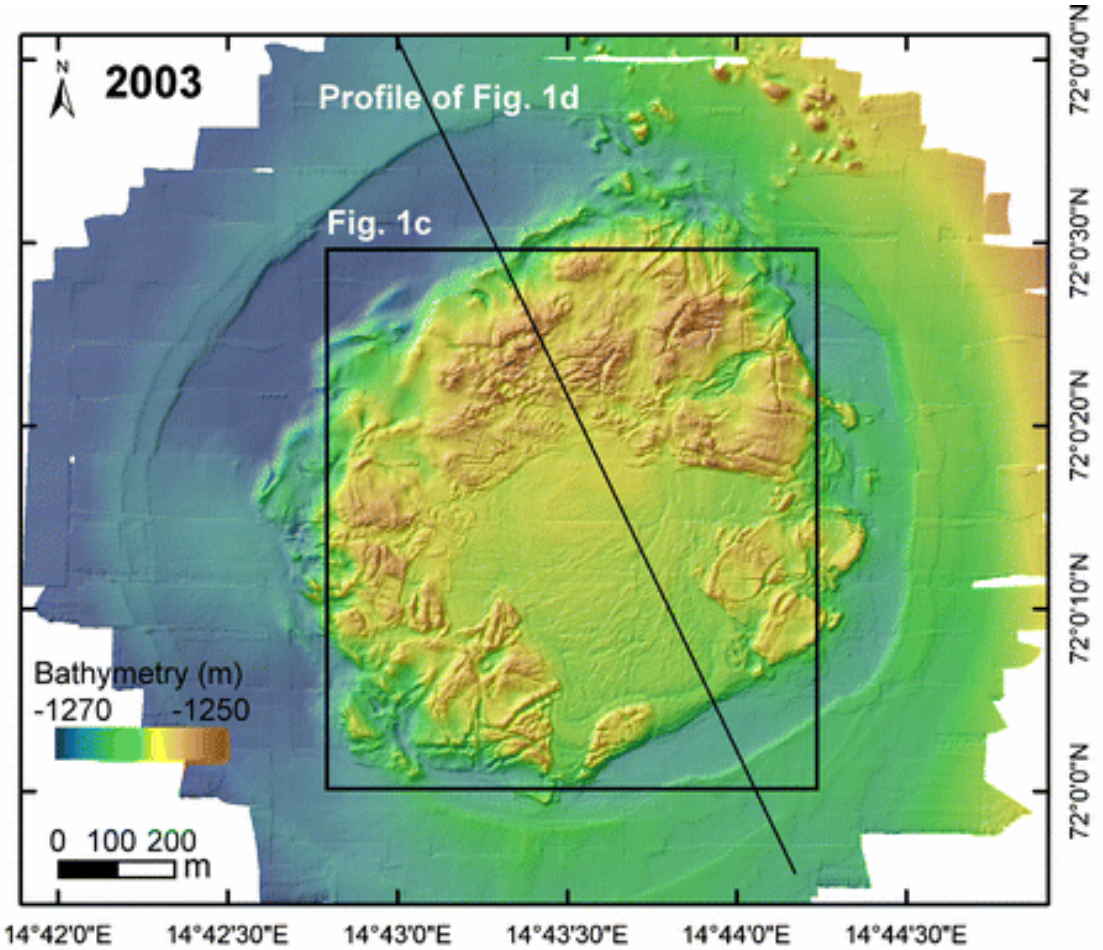

d

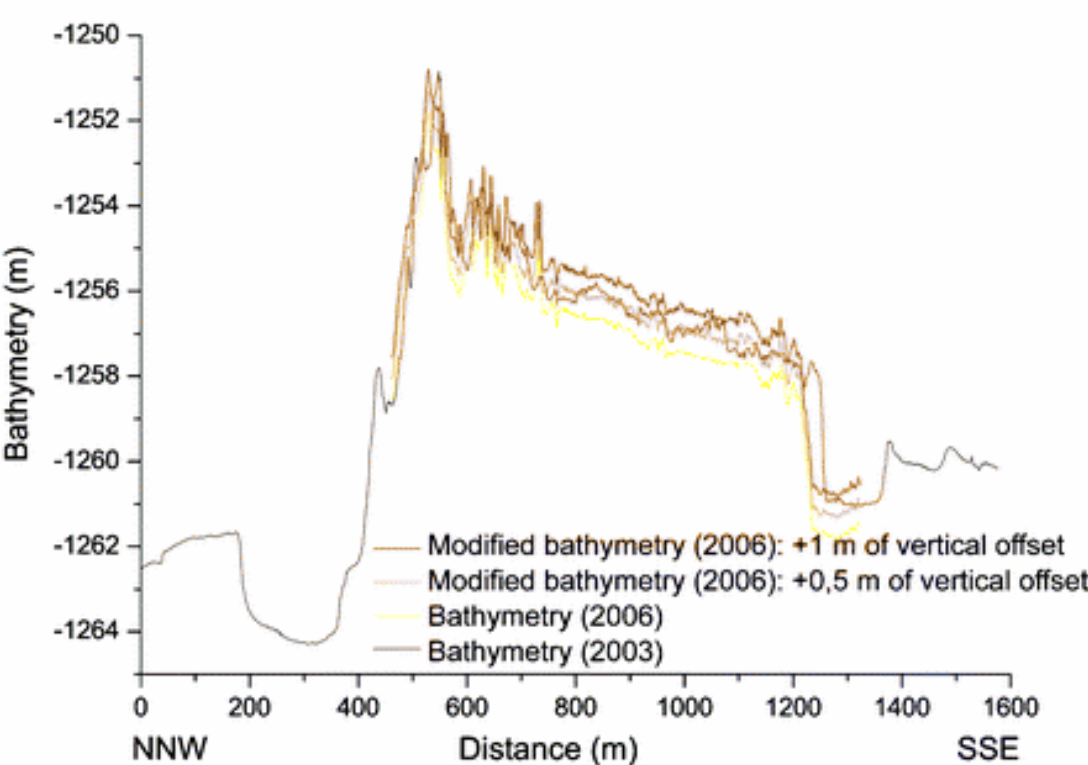


Fig. 1 a Arctic Ocean bathymetry map (Jakobsson et al. 2008) with location of the Håkon Mosby mud volcano (HMMV, star). b High-resolution (1-m grid) bathymetry map of the Håkon Mosby mud volcano acquired in 2003 (Edy et al. 2004) with location of the bathymetry profiles presented in d. c High-resolution (0.25-m grid) bathymetry map of the Håkon Mosby mud volcano acquired in 2006 as part of the Vicking cruise $(\mathrm{H}$. Nouzé, chief scientist). d High-resolution bathymetry profiles along a transect of the Håkon Mosby mud volcano (see profile location in b), using raw data from the 2003 survey as well as raw and corrected data from the 2006 survey
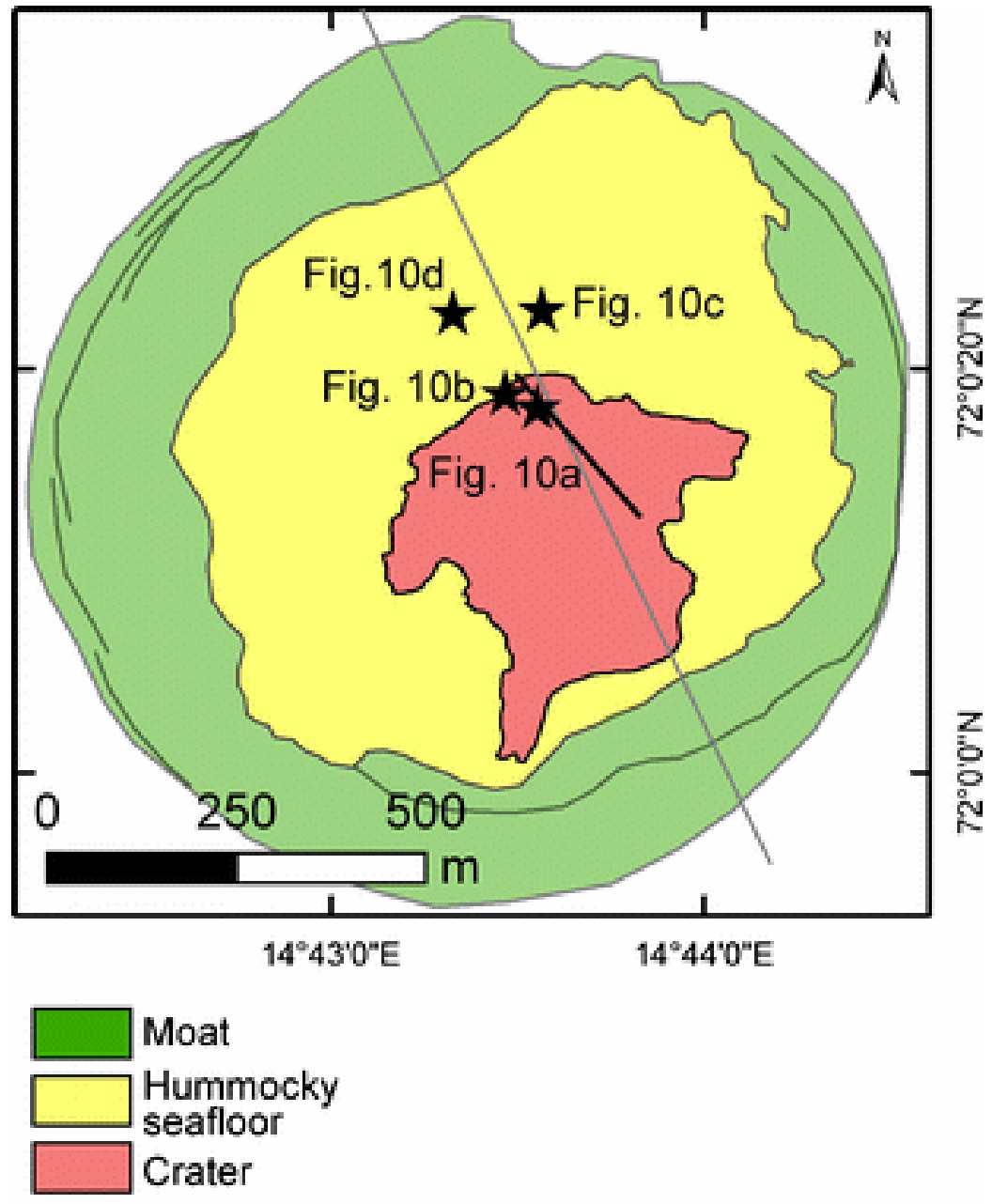

\section{Bathymetry profiles in Fig. 1d Temperature profile in Fig. 6 $\star$ Seafloor photos in Fig. 10}

Fig. 2 Simplified morphological zonation map of the Håkon Mosby mud volcano based on high-resolution bathymetry data acquired in 2003 (cf. Fig. 1b), displaying the main morphological units: the crater, the surrounding hummocky area, and the peripheral moat. Also reported are the locations of the bathymetry profile shown in Fig. 1d, the transect of temperature measurements (heat flow) shown in Fig. 6 and the photographs (stars) shown in Fig. 10 


\section{Vicking cruise (2006) data}

\section{ROV multibeam survey}

As part of the Vicking cruise of R/V Pourquoi pas? in July 2006, a high-resolution multibeam survey was carried out at the summit of the HMMV. The multibeam echosounder system used was a Reson 7125 mounted on the Victor ROV and operated at a frequency of 400 $\mathrm{kHz}$. Detailed seafloor maps were produced by means of the CARAIBES software (@)lfremer), yielding 0.25 - and $0.17-\mathrm{m}$ grids for the bathymetry and backscatter maps respectively. The survey encompassed the entire flat central and southern sectors (crater), thereby generating new seafloor maps of this part of the mud volcano previously covered by the 2003 survey (Fig. 1b). The new maps provide an opportunity to compare the morphology of the crater, where the most substantial morphological changes related to new mud eruptions since the 2003 survey would be suspected to occur.

\section{Mud temperature data}

Mud temperature was measured by means of a short temperature probe $(\sim 0.6 \mathrm{~m})$ pushed into the sediment from the manipulator arm of the Victor ROV. At full penetration, two sensors measured temperature at 0.25 and $0.55 \mathrm{~m}$ below the mud surface. Equilibrium mud temperatures were extrapolated from temperature records obtained while the probe was kept motionless in the mud for about 5 minutes and each sensor was being sampled every 5 seconds. In-situ mud temperature measurements obtained during three cruises at the HMMV between 2003 and 2006, including those made during the Vicking cruise in 2006, have been presented and discussed in detail by Feseker et al. (2008). In this paper, we will limit ourselves to a short recapitulation of changes in mud temperature recorded for this time period.

\section{Gas flare records}

A gas flare survey was carried out using the hull-mounted echosounder of the vessel (Simrad EA600, $38 \mathrm{kHz}$, beam width of $9.6^{\circ}$ ). Acoustic flares were observed on echograms recorded along several vessel tracks of the Vicking expedition, most run in a north-south direction, and at a vessel speed of abound 4 knots (Figs 7 and 8a). Records were all taken within a period of 6 days.

\section{Results}

\section{Morphological changes over the period 2003-2006}

A simple visual inspection of the two bathymetric maps produced in 2003 and 2006 clearly shows that the morphology of the external moat and hummocky seafloor regions of the mud volcano has not significantly changed, whereas the crater exhibits substantial changes (Fig. $1 \mathrm{~b}$ vs. Fig. 1c). Based on a comparison of bathymetry profiles across the mud volcano from the 2003 and 2006 surveys (Fig. 1d), these vertical differences appear however to be of small amplitude $(<1 \mathrm{~m})$ and become even smaller if we apply a depth correction to better adjust the mean water depth observed in 2006 to that in 2003 (Fig. 1d). A better fit is in particular observed in the moat at the SSE end of the profile for a $0.5 \mathrm{~m}$ to $1 \mathrm{~m}$ correction. This correction appears justified if there has been a drift in the calibration curve of the ROV pressure sensor from 2003 to 2006 (which we were not able to check), or a bias when 
converting the pressure measurement to water depth due to different determinations or temporal variability of the temperature and salinity profiles in the water column above the mud volcano. In Fig. 1d, the seabed in the crater shows more pronounced local bulges in 2003 than in 2006. This observation may be significant - changes could then be related to mud eruption events or mud movements in the crater in the time interval.

In order to further describe morphological changes in the crater over the period 2003 to 2006, slope maps were derived from the two detailed bathymetry maps with a $1 \mathrm{~m}$ grid size (Figs. 3a and b). Slope maps provide an enhanced representation of surficial morphological features potentially related to cracks and fissures at the seabed and/or defining the lateral extent of mud flows. Thus, slope maps help to reveal morphological changes. A major observation is that most of the morphological features identified in 2003 in the crater (Fig. 4a) are not visible on the 2006 map (Fig. 4b). Morphological changes appear to have affected the entire crater area, extending to the north-eastern and southern branches of the crater as well (Fig. 3), whereas the morphology of the surrounding hummocky zone appears largely unchanged. 

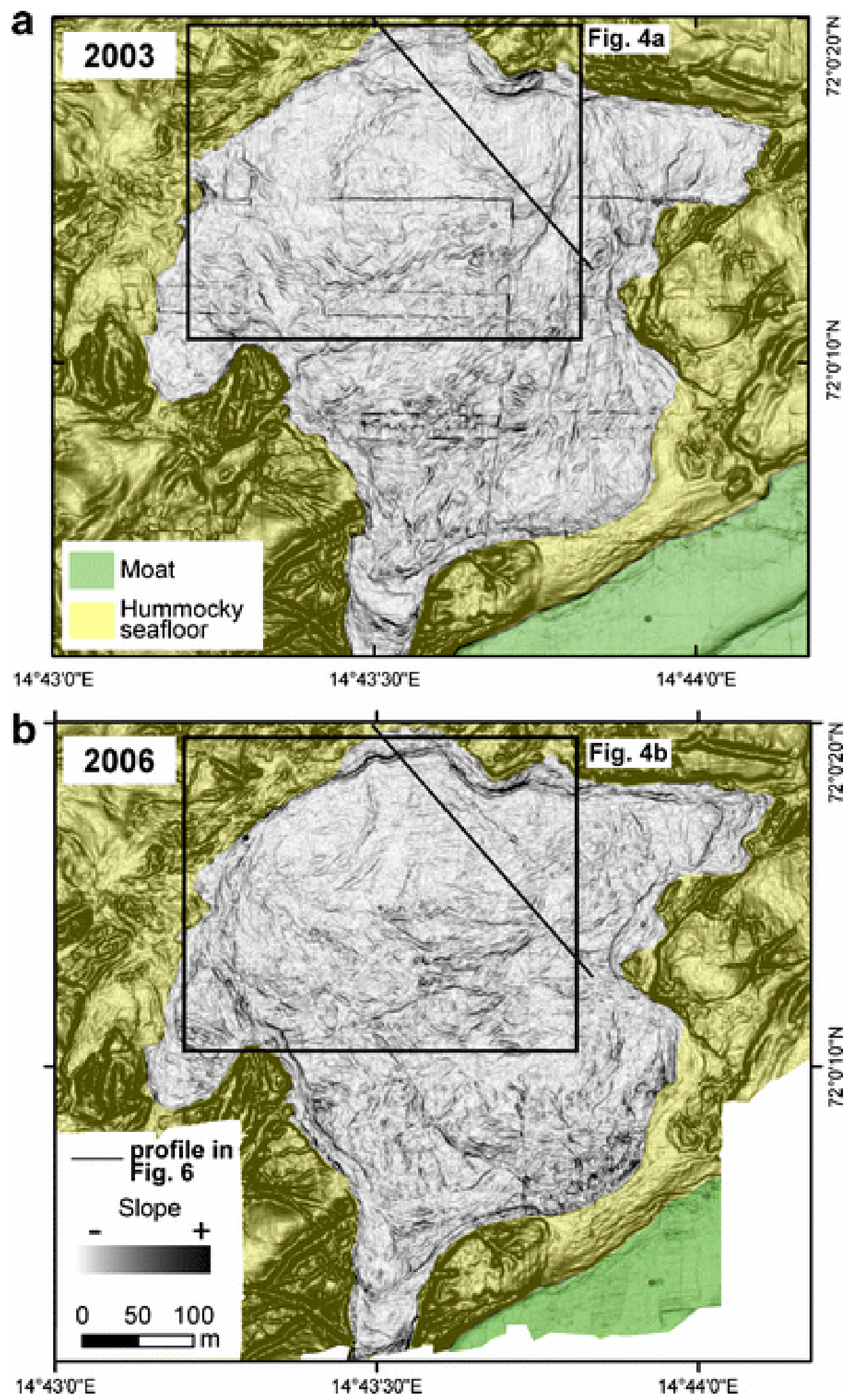

Fig. 3 Slope maps derived from 1-m bathymetry grids produced from ROV data acquired in 2003 (a) and 2006 (b) 


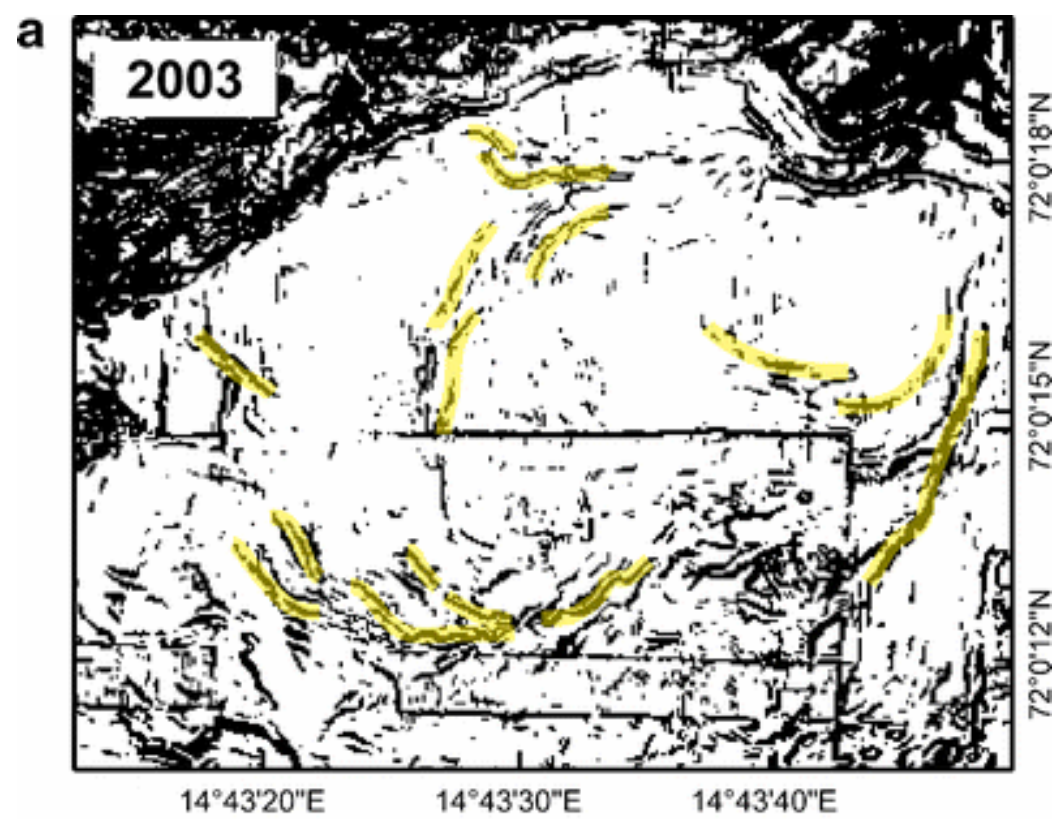

b

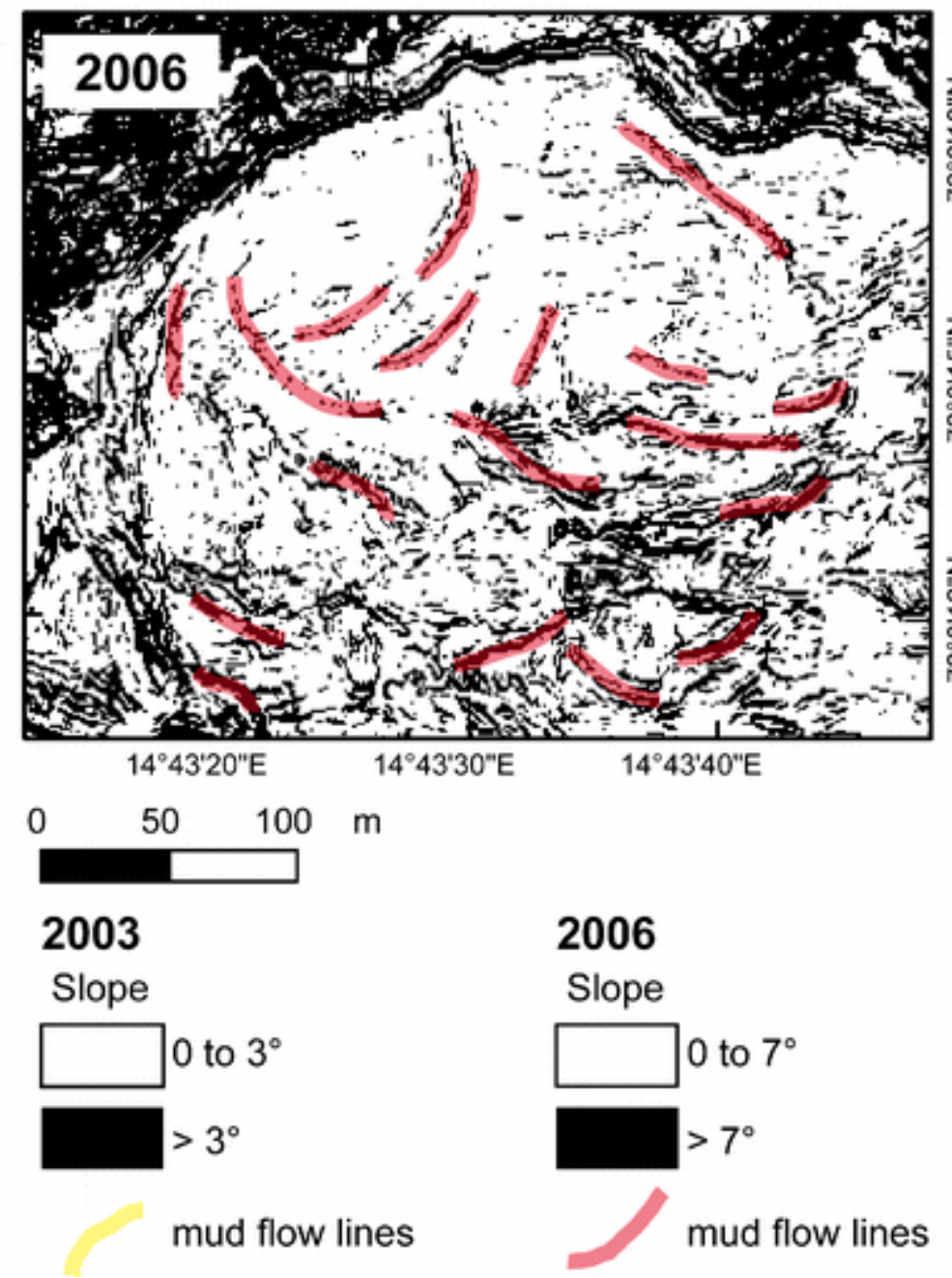

Fig. 4 Enlarged slope maps of the northern crater area from data acquired in 2003 (a) and 2006 (b), displaying major seabed relief features according to our interpretation. Note the changes in the spatial distribution and direction of these features between 2003 and 2006, which reveal new mud outflows 
Morphological changes are also supported by the seafloor backscatter data. The high and almost identical frequencies of the two multibeam echosounders used in 2003 and 2006 (455 and $400 \mathrm{kHz}$ respectively) imply similar acoustic penetration depths in the sediments and, thus, meaningful comparison of the backscatter images. The crater of the mud volcano, composed of mud breccia, a mixture of clasts and a silty matrix, exhibits higher backscatter than the fine-grained hemipelagic sediments of the surrounding area (Fig. 5). In the crater, the presence of low backscatter patches (a few metres to $50 \mathrm{~m}$ in width) is revealed by both the 2003 and 2006 datasets, but the spatial distribution of these patches differs between 2003 and 2006. The low backscatter patches may correspond to blocks of the surrounding hummocky seafloor area, assuming that these blocks could have drifted away from the central part of the volcano possibly in response to mud eruptions or mud movements at the surface of the mud volcano. The origin of the low backscatter patches could not be determined from ROV seafloor video records. 

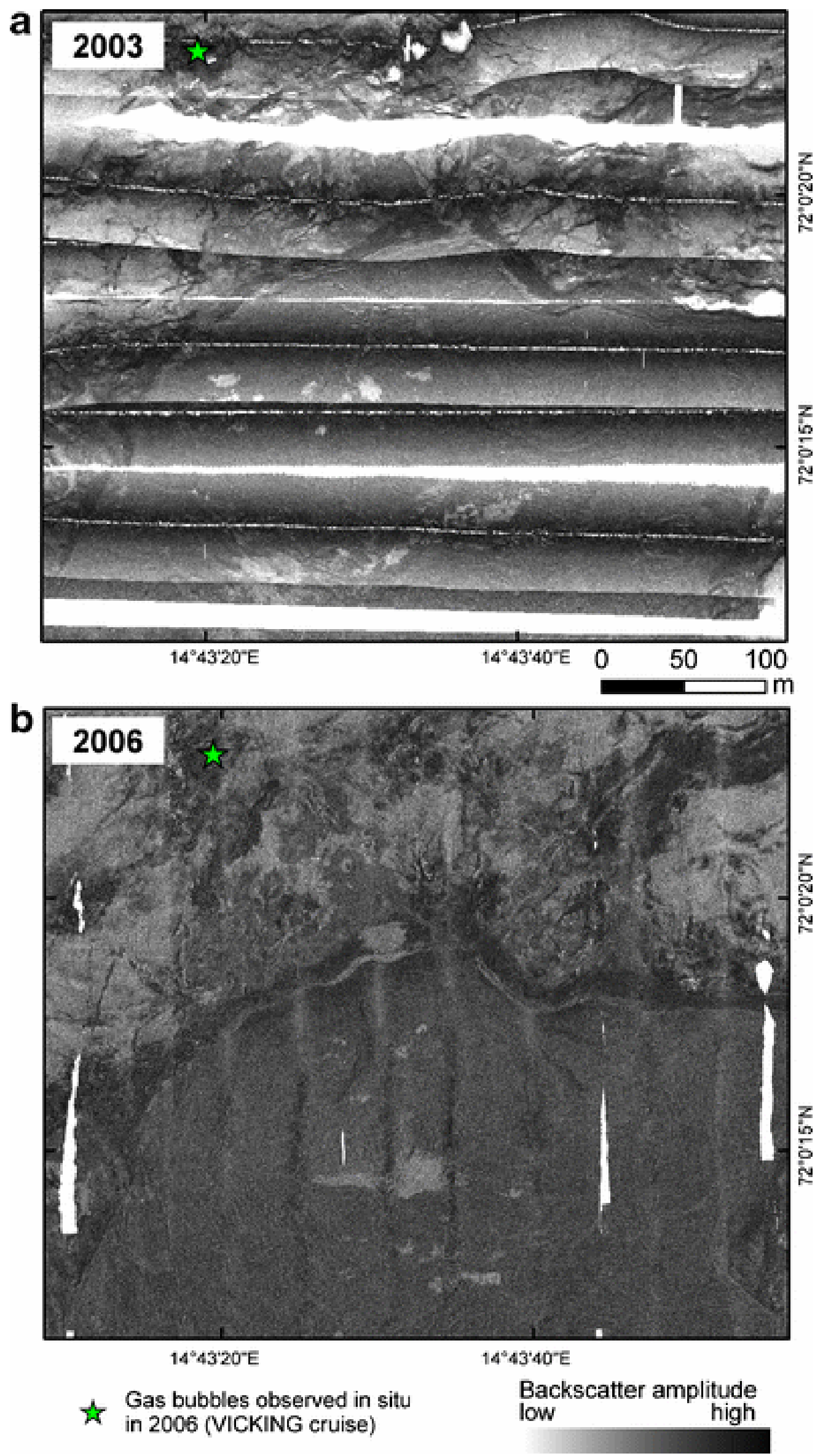
Fig. 5 a High-resolution (0.5-m grid) backscatter map of the northern part of the Håkon Mosby mud volcano acquired in 2003 with a Reson multibeam mounted on the Victor ROV and operated at $455 \mathrm{kHz}$. b High-resolution (0.17-m grid) backscatter map of the northern part of the Håkon Mosby mud volcano acquired in 2006 with a Reson multibeam mounted on the Victor ROV and operated at $400 \mathrm{kHz}$. Note the changes in the spatial distribution of the low-backscatter patches within the central part of the mud volcano from 2003 to 2006

\section{Mud temperature changes in the crater}

Assuming that sediment temperature is an indicator for mud volcano activity, all temperature data collected over recent years clearly show that the most active area of the HMMV is located near the geometrical centre of the mud volcano in the northern part of the crater (Kaul et al. 2006; Feseker et al. 2008). Perez-Garcia et al. (2009) present additional temperature data collected in 2007 showing that the focus of the temperature anomaly coincides with the centre of the conduit identified in acoustic sediment chirp profiles.

Results of shallow temperature measurements along a transect line across the active centre collected in 2003 and 2006 are presented in Fig. 6. Repeated sediment temperature measurements provide evidence for persistently high temperatures, although the extremely high near-seabed sediment temperature gradients of up to more than $40{ }^{\circ} \mathrm{C} / \mathrm{m}$ in 2003 were not found in 2006. These observations reveal the complexity of the mud temperature distribution at a small spatial scale of a few tens of meters. They may indicate upward movement of mud during a very active phase of the mud volcano shortly before the temperature measurements in 2003 or they may reflect an overall decrease in the strength of the pore fluid advective flow through the seabed between 2003 and 2006.

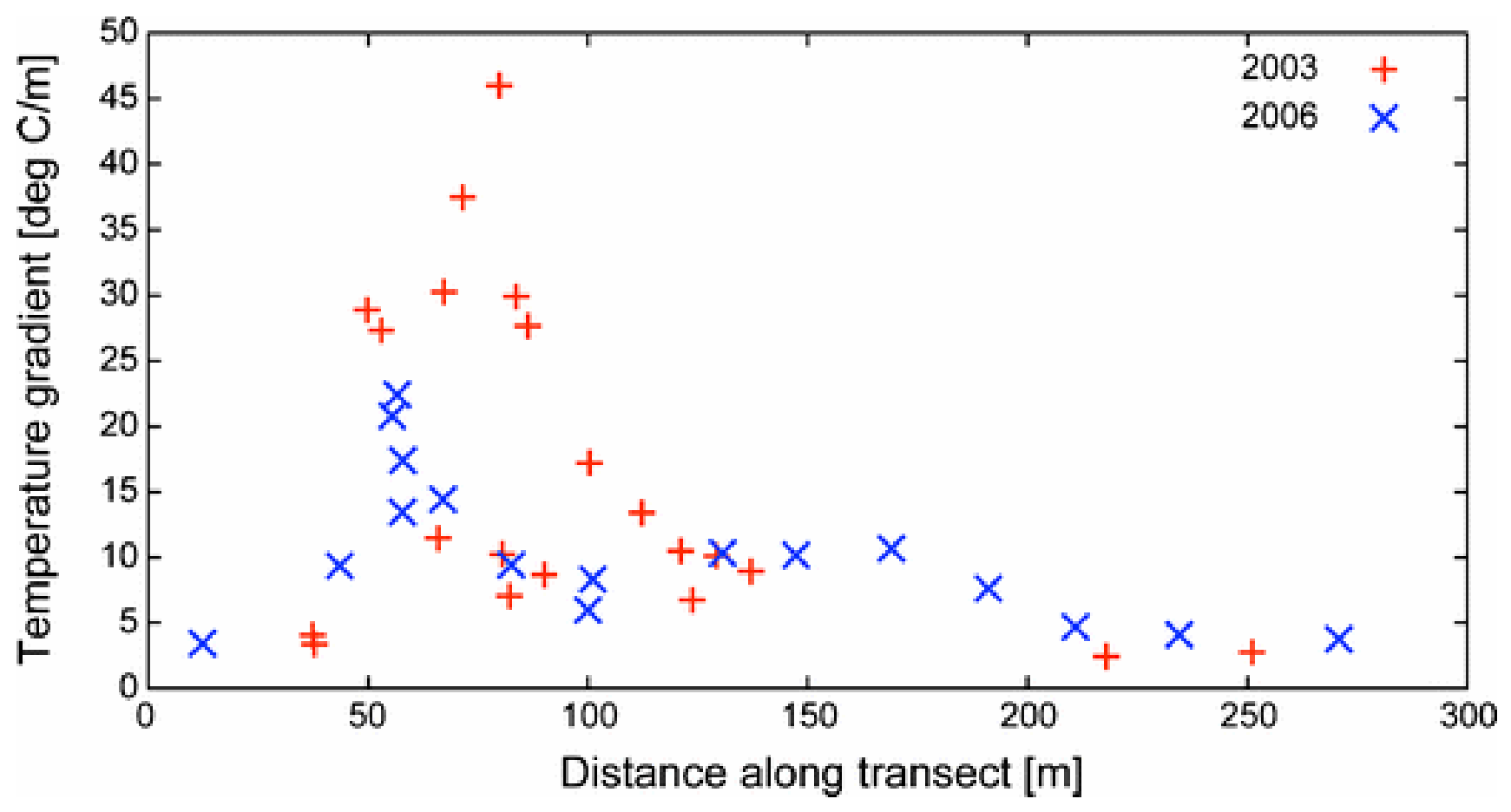

Fig. 6 Near-seabed sediment temperature gradients measured in 2003 (red) and 2006 (blue) along a profile crossing the active centre of the Håkon Mosby mud volcano (see Fig. 2 for location of the transect) 
Large acoustic gas flares were detected during the Vicking cruise (2006) in the water column above the mud volcano. Some flares could be traced down to the seabed (Fig. 7a), whereas othes lacked visible "roots" connecting them to the seabed (Fig. 7b). This is simply interpreted as resulting from bottom currents deforming the acoustic flares that, instead of being vertical as would be expected in the absence of bottom currents activity, extended obliquely from the seabed. Due to the limited beam angle of the echosounder, the acoustic record could show only part of the flare, possibly lacking its lower and upper or part. In the present case, flares were detected rising up to $600 \mathrm{~m}$ from the seabed (Fig. 8a).

The gas source area has been delimitated by the extreme geographic positions of the flare echoes contiguous to the sea floor (Fig. 8b). Furthermore, an envelop area of all flare echoes has been defined from the extreme geographic positions of all recorded echoes either contiguous or not to the seabed (Fig. 8b). The acoustic gas flares appear to be associated mainly with the hummocky northern seabed region of the mud volcano. The extent of the gas source area is equivalent to the footprint on the seabed of the vessel echosounder $(213 \mathrm{~m}$ for a range of $1270 \mathrm{~m}$ ). The low spatial resolution does not allow us to locate individual gas vents. A location map of all central positions (defined as mid-positions between extreme positions of the flares on the seabed) includes in its eastern part the Champagne gas vent reported by Sauter et al. (2006) but not found during the Vicking cruise of 2006. In the western part, the Victor ROV, equipped with a vertical split-beam echosounder (Simrad ER60 $200 \mathrm{kHz}$, beam width of $6.3^{\circ}$ ) was navigated at about $40 \mathrm{~m}$ above the seabed at a speed of approx. 1 knot. A single acoustic gas flare was detected (Fig. 9), followed quickly by video inspection of the underlying seabed that revealed a string of free gas bubbles rising from the seafloor (Fig. 10). Whether there were other active gas vents or not could not be answered from the short survey we were able to run during this cruise.

Target strength values of the gas vent bubbles from the ROV records vary between -43.7 and $-59.8 \mathrm{~dB}$, with an average value of $-49.21 \mathrm{~dB}$. Using these data and the backscattering gaseous sphere model of Stanton (1989), we estimate the bubble diameter to be between 3.6 and $26.6 \mathrm{~mm}$, with an average value of $13.8 \mathrm{~mm}$. These values are similar to those reported in other studies (Rehder et al. 2002, Greinert and Nützel 2004, Sauter et al. 2006). The highest values might result from coalescent smaller bubbles. The mean volume backscattering strength (MVBS over 132 pings) of the gas flare was $-40.69 \mathrm{~dB} \mathrm{~m}^{-1}$, giving an average density of 7.11 bubbles per $\mathrm{m}^{3}$ (range 0.1 to 64.7 ) across the vertical section of the gas flare record. Assuming that targets are spherical bubbles of methane, the average gas volume would be $9.8 \mathrm{~mL} \mathrm{~m}^{-3}$, with a maximum value of $89 \mathrm{~mL} \mathrm{~m}^{-3}$ in the central part of the flare (Fig. 9b). 


\section{a}

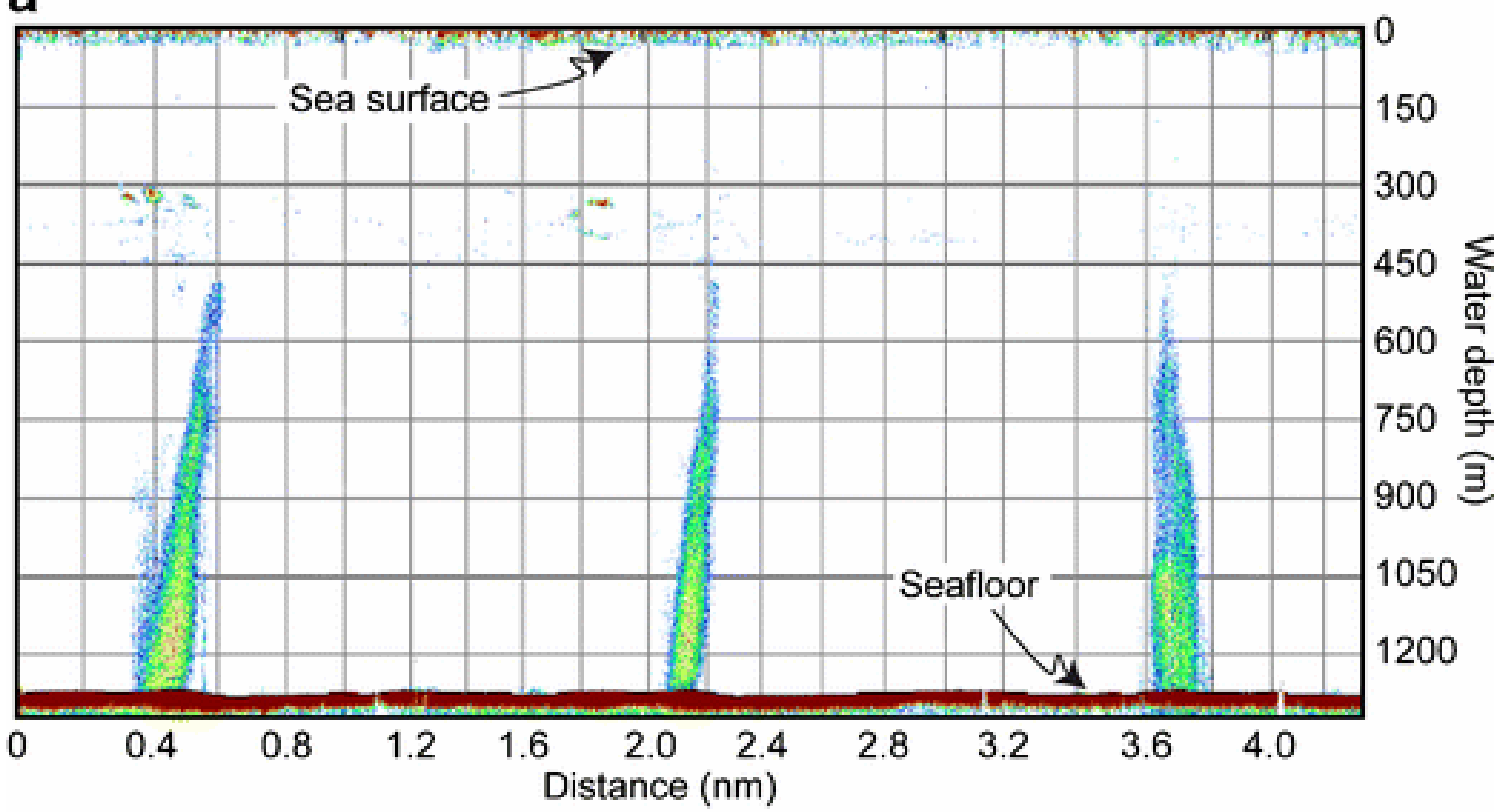

b

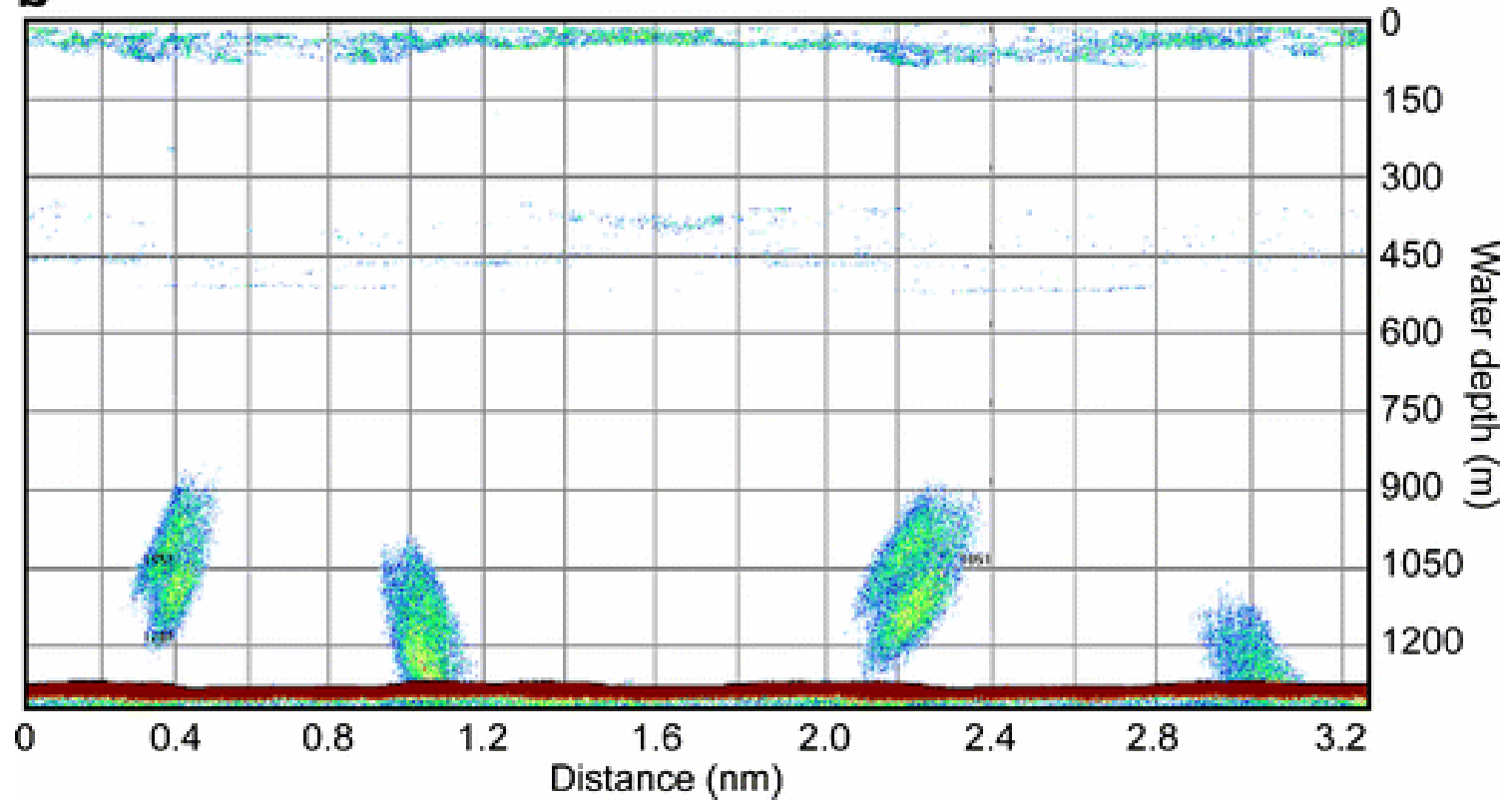

Fig. 7 Acoustic anomalies detected in the water column above the Håkon Mosby mud volcano using the 38-kHz echosounder of the R/V Pourquoi pas? during the Vicking cruise in 2006, and interpreted as gas flares: examples of a flares with echoes contiguous to the seafloor, b off-bottom flares. Different orientations of flares correspond to different ship tracks. Scattering volume processing threshold was set to $-75 \mathrm{~dB}$ 
a

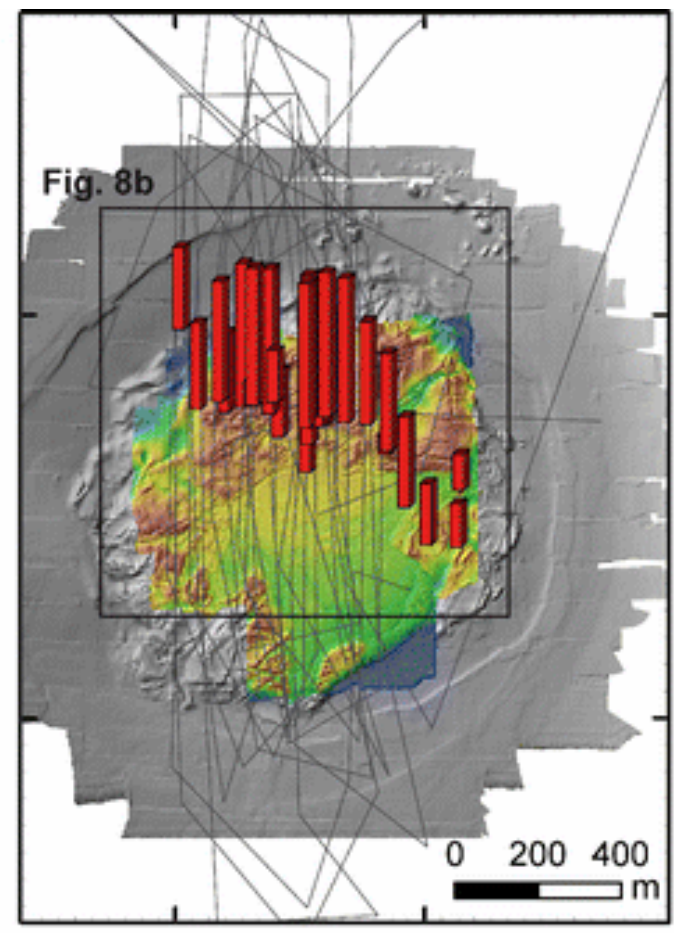

$14^{\circ} 43^{\prime} 0^{\prime \prime E}$

\section{Legend}

2003 bathymetry $(\mathrm{m}) \quad 2006$ bathymetry $(\mathrm{m})$

$-1270$

$-1250$

$-1266$

$-1250$

\section{Maximum height above \\ the seafloor $(\mathrm{m})$}

of the acoustic gas flare

Victor ROV track lines

Acoustic gas flare source point (2006 VICKING cruise)

Gas bubbles observed in situ in 2006 (VICKING cruise)

$\checkmark \quad$ Gas bubbles observed in situ in 2003 after Sauter et al. 2006

Potential location of in situ gas source

Spatial extension of the acoustic gas flare detected in the water column

b

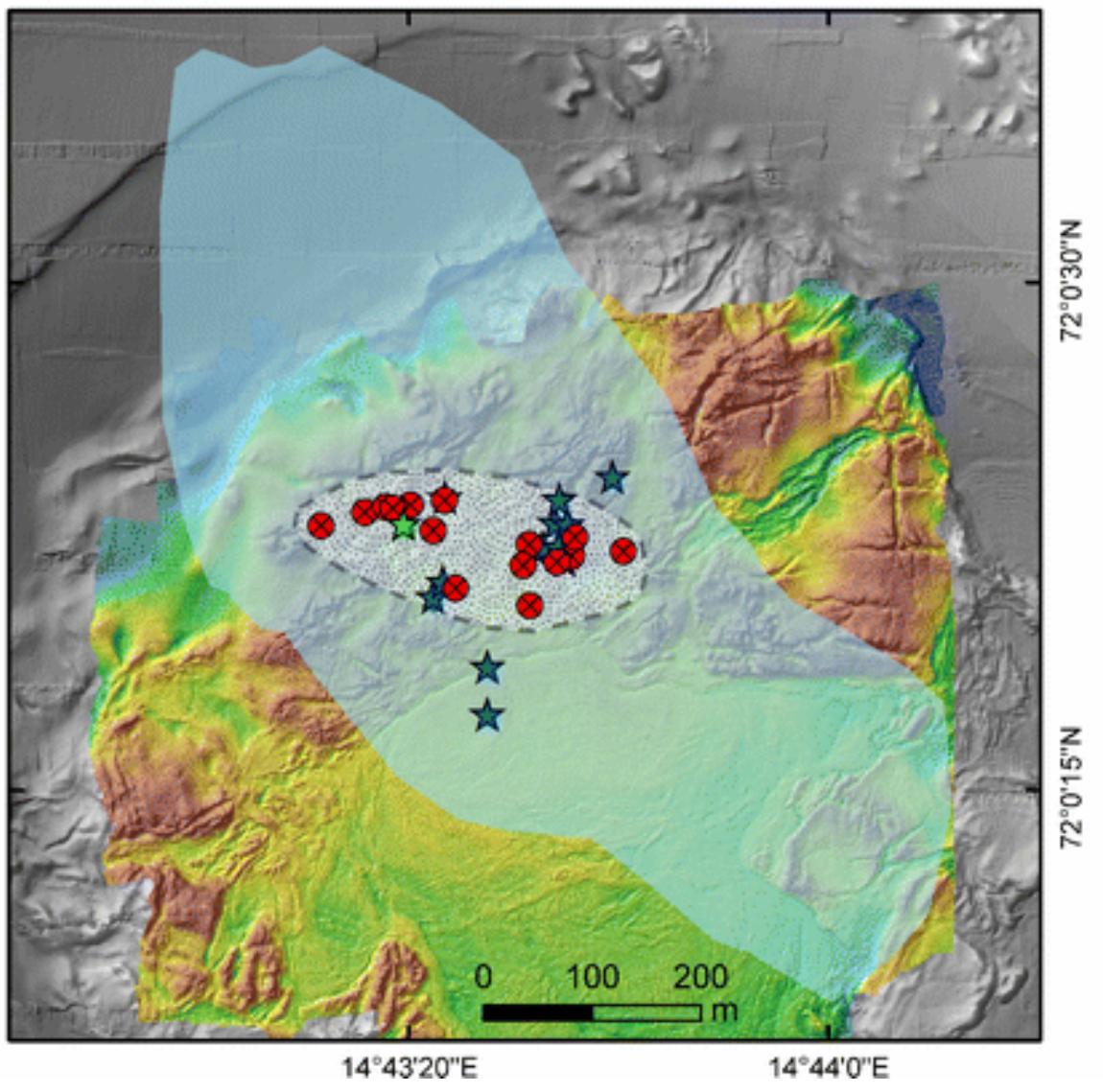

Fig. 8 a Track lines of acoustic surveys, with heights above the seafloor of recorded gas flares. Gas source locations on tracks are defined as mid-distances between the beginning and end of echoes contiguous to the seabed. b Seabed imprints of all echoes contiguous (inner area) or not (outer area) to the seabed. Gas bubble sites observed in 2003 by Sauter et al. (2006) are also reported 

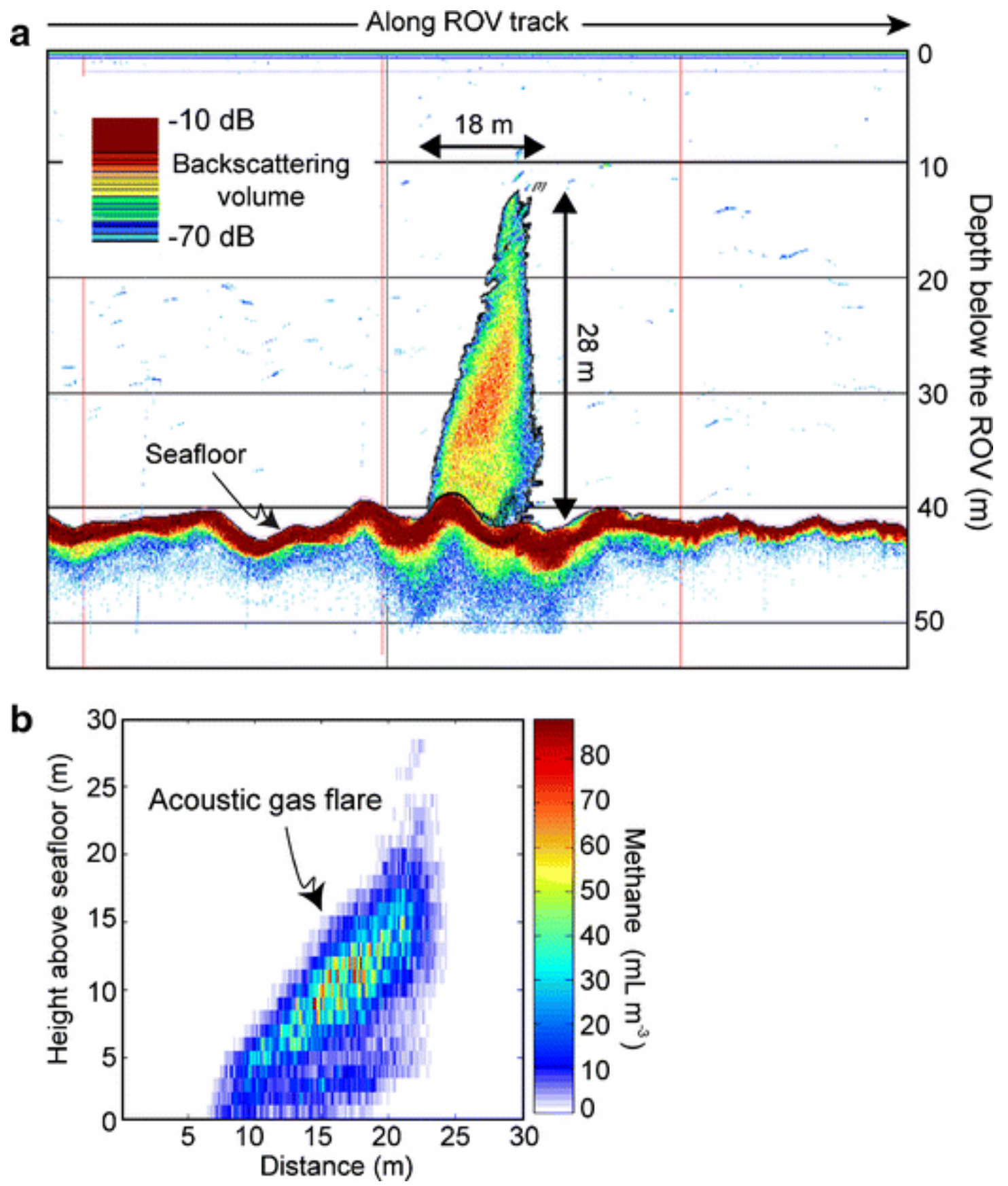

Fig. 9 a Acoustic gas flare detected by a 200-kHz Simrad ER60 echosounder mounted on the Victor ROV in 2006 (Vicking cruise) above the seafloor of the Håkon Mosby mud volcano. The scattering volume threshold was set to $-70 \mathrm{~dB}$. The height of the gas flare is $28 \mathrm{~m}$, with a mean volume backscattering strength of $-41 \mathrm{~dB} \mathrm{~m}^{-1}$, as estimated by Movies + software (@lfremer; Weill et al. 1993; Berger et al. 2007). b Estimated distribution of methane volume across the vertical section of the acoustic flare 

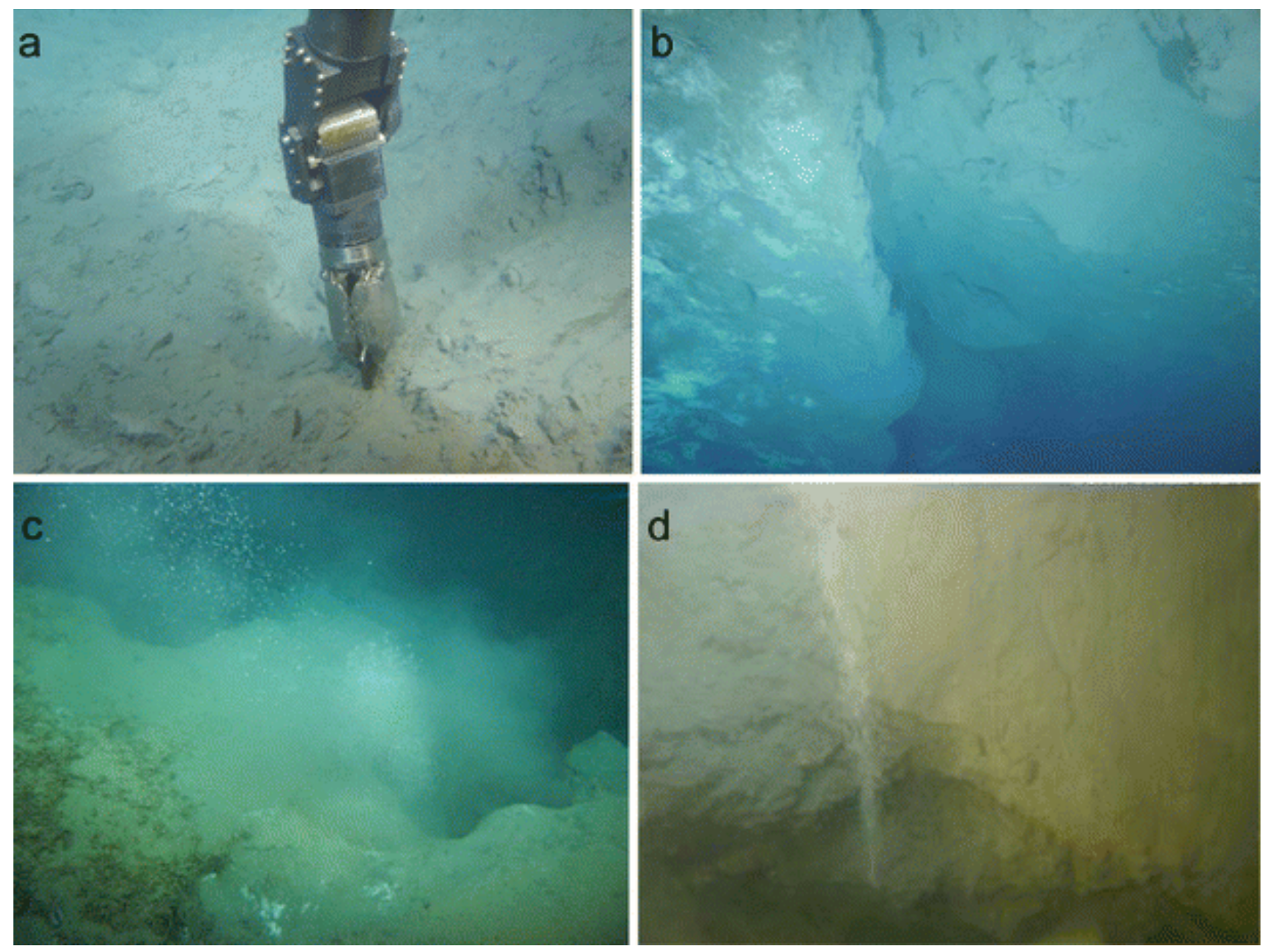

Fig. 10 Near-bottom Victor ROV photographs of the seabed at the Håkon Mosby mud volcano (for locations, see Fig. 2). a Sampling fresh mud in the northern part of the crater. b Active faulting at the transition between the crater and the hummocky periphery. c String of gas bubbles coated with hydrate at the Champagne site discovered using Victor ROV during the ARK-XIX/3b cruise of the R/V Polarstern in 2003 (Sauter et al. 2006). d String of gas bubbles escaping through a fracture of the hummocky seabed at the Vicking site discovered in 2006 (present study)

\section{Discussion}

We interpret morphological changes observed at the seabed in the crater of the HMMV between 2003 and 2006 as being a consequence of mud eruption events. Freshly erupted mud has been observed both in 2003 and 2006 (Fig. 10). The question arises of the nature of those events. Morphological changes have been detected over the entire crater, as highlighted by the comparative slope and backscatter maps of 2003 and 2006, and there is no clear evidence for a single centre of mud eruption (Figs. 3, 4 and 5). Furthermore, the lack of major changes in a topographic profile across the mud volcano from 2003 to 2006 (Fig. $1 d$ ) suggests that the total volume of mud erupted at the surface of the mud volcano has been small. An interpretation accounting for our observations is that several small-volume mud outflow events occurred at distinct locations in the crater, and possibly at different times, between 2003 and 2006. The HMMV mud eruption activity could then be described as an 
intermittent modest flow of mud at distinct locations in the crater, similar to mud flows from small mud cones (gryphons) and mud pools at the surface of several onshore mud volcanoes, e.g. the Boulganack mud volcano in Ukraine (Herbin et al. 2008). In this respect, onshore and offshore mud volcanoes would behave much alike.

Active faulting at the sharp transition from the crater to the hummocky area of the HMMV (Fig. 10) expresses differential vertical movements between the two morphological units. Vertical movements in the crater are presumably controlled by the subsidence induced by dewatering and consequent loss of volume of the freshly erupted mud, and by mud outflows and/or deeper mud movements in the feeder channel and the mud chamber (Perez-Garcia et al., 2009). Vertical movements in the hummocky area are expected to occur mainly associated with large eruption events. Thus vertical movements in the hummocky area are likely to be of smaller amplitude than in the crater, which may account for the sharp transition from the crater to the hummocky area and an active deformation at this transition.

Mud temperature observations point to persistently high temperatures at shallow depth in the crater at the centre of the mud volcano between 2003 and 2006. Kaul et al. (2006) showed that a $4 \mathrm{~m}$ thick flow of warm mud would cool up by conduction in only 3-4 months after an eruption event, and that high temperatures within the mud flow (in the sub-bottom depth range of measurements at the HMMV, between 20 and $60 \mathrm{~cm}$ ) would dissipate in only a few days. Thus, the persistence of high temperatures between 2003 and 2006 seems to rule out the interpretation of the heat anomaly as being a consequence of conductive cooling of fresh mud flows, since temperature measurements are unlikely to have all been made only a short time after an eruption event, which would be required by this interpretation. Instead, the high temperatures demonstrate a persistently high activity of warm fluid discharge through the surface of the crater. Vertical specific discharge rates estimated from mud temperature profiles are known to reach several meters per year in the crater at the centre of the mud volcano (Feseker et al. 2008). The small-scale spatial variability observed in the mud temperature distributions (Fig. 6) may reflect local fluid and mud movements at shallow depth in the mud volcano, possibly associated with events of modest mud outflows that have also been suggested from morphological changes.

Our acoustic observations during the Vicking cruise of 2006 confirm the existing evidence of long-lasting degassing activity at the surface of the HMMV (Sauter et al. 2006). According to our observations in 2006, the estimated gas source area (Fig. 8b) is mostly limited to the hummocky seabed region (Fig. 2, Unit 2), where focused gas venting occurs through sediment cracks. One reason for this could be the difference in sediment properties recorded for the crater and in the hummocky periphery. In the crater, broadly-distributed pore water advection through a low-viscosity, highly permeable mud could release most of the gas transported with the mud to the seabed in a dissolved phase. In contrast, this gas could accumulate under a low-permeability sediment cover, utilizing seabed cracks to escape at localized vents in the hummocky area. Interestingly, the Champagne site, a major gas vent discovered in the hummocky region in 2003, was not found in 2006. However, our observations during the Vicking cruise in 2006 may have been not exhaustive enough to conclude with confidence that the Champagne site was extinct at the time. Our estimated locations of the gas vents suggest at least one active site in the eastern gas source area (Fig. 8b). This site could actually be the Champagne site, which we would have missed during the 2006 Vicking cruise; alternatively it could be a new site not yet active or yet discovered in 2003. Moreover, a new major gas vent, the so-called Vicking site, was found in 2006 in the western part of the gas source area. This site is located about $150 \mathrm{~m}$ away from the Champagne site and is therefore quite distinct from it. Although the Vicking site had not been previously reported, it cannot be stated with certainty that this site was not already active in 2003. To conclude on this aspect, Vicking cruise observations in 2006 tend to suggest but do not prove a different distribution of active gas vents with respect to 2003.

Seabed pictures in Fig. 10 show that at the Champagne site, fresh mud covers the seabed surrounding the vent over lateral distances of 2-3 $\mathrm{m}$. The fresh mud is thought to result from deposition of mud particles emitted in the gas bubble jet. Mud particles could be more abundant in the jet at times of increased gas emission at the vent, possibly including the time 
of initiation of the venting activity. The fresh mud cover has a higher acoustic backscatter than the hemipelagic sediment. Gas venting areas could be then characterized by a higher backscatter. In turn, a higher backscatter on seabed maps could be used as an indication of gas venting, even after extinction of the venting activity. An inspection of the acoustic backscatter map (Fig. 5) shows that several spots in the hummocky seabed region of the Håkon Mosby mud volcano are characterized by higher backscatter. Whether these areas of higher backscatter are explained by a fresh mud cover possibly deposited at times of active gas venting, as suggested above, would deserve further ground-truthing by video inspection.

\section{Summary and conclusion}

A comparison of observations made at the HåkonMosby mud volcano offshore northern Norway in 2003 and 2006 reveals significant changes in the morphology of the crater, as well as persistently high mud temperatures at shallow depth below the seabed. The observations also confirm a high activity of free gas emission, but locations of gas vents may have changed over the 3-year time interval. Morphological changes may have been produced by several small-volume mud outflows occurring at distinct locations in the crater, and possibly at different times, between 2003 and 2006. Persistently high temperatures of the mud at shallow depth in the crater imply upward fluid advection at rates of several metres per year. Although modest mud eruption events are suggested by our observations, we have identified evidence of significant change in activity even over short time intervals of only 3 years. This may be a characteristic shared by other submarine mud volcanoes, notably those considered to be in a quiescent stage. It also makes the Håkon Mosby mud volcano an important natural laboratory to monitor the dynamics of aqueous and gas seepage, as well as associated ecosystem response in a high-latitude region.

\section{Acknowledgements}

The Vicking cruise (2006) of the R/V Pourquoi pas? using Victor ROV was carried out in the frame of the HERMES Project funded by the European Commission's Framework Sixth Programme, under the priority Sustainable Development, Global Change and Ecosystems, EC Contract No. GOCE-CT-2005-511234. We acknowledge the efficient assistance of the Master and Crew of the R/V Pourquoi pas?, and the Victor ROV team during the Vicking cruise. We thank Ifremer colleagues, Alain Normand for processing the multibeam data, and Catherine Satra and Marie-Claire Fabri for their help in the development and use of the GIS. We are grateful to Doug Masson and George Delisle for helpful reviews.

\section{References}

Aliyev A A, Guliyev I S, Belov I S (2002) Catalogue of recorded eruptions of mud volcanoes in Azerbaijan (for period of years 1810-2001). Nafta Press, Baku, 87 pp

Berger L, Durand C, Marchalot C (2007) Movies+ User Manual version 4.4. Ifremer, 72 pp

de Beer D, Sauter E, Niemann H, Kaul N, Foucher J-P, Witte U, Schlüter M, Boetius A (2006) In situ fluxes and zonation of microbial activity in surface sediments of the Håkon Mosby Mud Volcano. Limnology and Oceanography 51:1315-1331

Delisle G, Von Rad U., Andruleit H, Von Daniels C H, Tabrez A R, Inam A (2002) Active mud volcanoes on- and offshore eastern Makran, Pakistan. International Journal of Earth Sciences 91:93-110

Deville E and Guerlais SH (2009) Cyclic activity of mud volcanoes: Evidences from Trinidad (SE Caribbean). Marine and Petroleum Geology 26:1681-1691 
Dimitrov L I (2002) Mud volcanoes-the most important pathway for degassing deeply buried sediments. Earth Science Review 59:49-76

Edy C, Bisquay H, Foucher J-P, Opderbecke J, Simeoni P, Allais A-G, Beyer A, Jerosch K, Rathlau R (2004) Microbathymetry of the Håkon Mosby mud volcano off northern Norway: results of a ROV-born multibeam survey. Geophysical Research Abstracts 6:4619

Etiope G, Milkov A V (2004) A next estimate of global methane flux from onshore and shallow submarine mud volcanoes to the atmosphere. Environmental Geology 46:997-1002

Feseker T, Dählmann A, Foucher J P, Harmegnies F (2009) In-situ sediment temperature measurements and geochemical porewater data suggest highly dynamic fluid flow at Isis mud volcano, eastern Mediterranean Sea. Marine Geology 261:128-137

Feseker T, Foucher J P, Harmegnies F (2008) Fluid flow or mud eruptions? Sediment temperature distributions on Håkon Mosby mud volcano, SW Barents Sea slope. Marine Geology 247:194-207

Foucher J-P, Westbrook G K, Boetius A, Ceramicola S, Dupré S, Mascle J, Mienert J, Pfannkuche O, Pierre C, Praeg D (2009) Structure and drivers of hydrocarbon seep ecosystems in the European seas: An overview from HERMES results. Oceanography 22:92-109

Greinert J, Nützel B (2004) Hydroacoustic experiments to establish a method for the determination of methane bubble fluxes at cold seeps. Geo-Marine Letters 24:75-85

Herbin J P, Saint-Germès M, Maslakov N, Shnyukov E F, Vially R (2008) Oil seeps from the "Boulganack" mud volcano in the Hertch Peninsula (Ukraine-Crimea). Study of the mud and the gas; Inferences for the petroleum potential. Oil \& Gas Science and Technology. Revue IFP 63:609-628

Hjelstuen B O, Eldholm O, Faleide J I, Vogt P R (1999) Regional setting of Håkon Mosby Mud Volcano, SW Barents Sea margin. Geo-Marine Letters 19:22-28

Jakobsson M, Macnab R, Mayer L, Anderson R, Edwards M, Hatzky J r, Schenke H W, Johnson P (2008) An improved bathymetric portrayal of the Arctic Ocean: Implications for ocean modeling and geological, geophysical and oceanographic analyses. Geophysical Research Letters 35, L07602, doi:10.1029/2008GL033520

Jerosch K, Schlüter M, Foucher J-P, Allais A-G, Klages M, Edy C (2007) Spatial distribution of mud flows, chemoautotrophic communities, and biogeochemical habitats at Håkon Mosby Mud Volcano. Marine Geology 243:1-17

Judd A G, Hovland M (2007) Seabed Fluid Flow. The Impact on Geology, Biology and the Marine Environment, Cambridge University Press 293 pp

Kaul N, Foucher J-P, Heesemann M (2006) Estimating mud expulsion rates from temperature measurements on Håkon Mosby Mud Volcano, SW Barents Sea. Marine Geology 229:1-14

Kopf A J (2002) Significance of mud volcanism. Reviews of Geophysics 40(2) 1005, doi:10.1029/2000RG000093

Mazzini A, Svensen H, Akhmanov G G, Aloisi G, Planke S, Malthe-Sørenssen A, Istadi B (2007) Triggering and dynamic evolution of the LUSI mud volcano, Indonesia. Earth and Planetary Science Letters 261:375-388

Milkov A, Vogt P, Cherkashev G, Ginsburg G, Chernova N, Andriashev A (1999) Sea-floor terrains of Håkon Mosby Mud Volcano as surveyed by deep-tow video and still photography. Geo-Marine Letters 19:38-47

Milkov A V (2000) Worldwide distribution of submarine mud volcanoes and associated gas hydrates. Marine Geology 167:29-42

Milkov A V, Vogt P R, Crane K, Lein A Y, Sassen R, Cherkashev G A (2004) Geological, geochemical, and microbial processes at the hydrate-bearing Håkon Mosby mud volcano: a review. Chemical Geology 205:347-366

Perez-Garcia C, Feseker T, Mienert J, Berndt C (2009) The Håkon Mosby mud volcano: 330 000 years of focused fluid flow activity at the SW Barents Sea slope. Marine Geology 262:105-115 
Rehder G, Brewer P W, Peltzer E T, Friederich G (2002) Enhanced lifetime of methane bubble streams within the deep ocean. Geophysical Research Letters 29 1731, doi:10.1029/2001GL013966

Sauter E J, Muyakshin S I, Charlou J-L, Schluter M, Boetius A, Jerosch K, Damm E, Foucher J-P, Klages M (2006) Methane discharge from a deep-sea submarine mud volcano into the upper water column by gas hydrate-coated methane bubbles. Earth and Planetary Science Letters 243:354-365

Stanton T K (1989) Simple approximate formulas for backscattering of sound by spherical and elongated objects. Journal of the Acoustical Society of America 86:1499-1510

Vanreusel A, Andersen A C, Boetius A, Connelly D, Cunha M R, Decker C, Hilario A, Kormas K A, Maignien L, Olu K, Pachiadaki M, Ritt B, Rodrigues C, Sarrazin J, Tyler P, Van Gaever S, Vanneste H (2009) Biodiversity of cold seep ecosystems along the European margins. Oceanography 22:110-127

Vogt P R, Gardner J, Crane K (1999) The Norwegian-Barents-Svalbard (NBS) continental margin: Introducing a natural laboratory of mass wasting, hydrates and ascent of sediment, pore water, and methane. Geo-Marine Letters 19:2-21

Weill A, Scalabrin C, Diner N (1993) MOVIES-B: an acoustic detection description software. Application to shoal species classification. Aquatic Living Resources 6:255-267 